\title{
Institutional Work and Infrastructure Public-Private Partnerships (PPPs): The Roles of Religious Symbolic Work and Power in Implementing PPP Projects
}

\begin{abstract}
Purpose- The public and project management disciplines increasingly adopt neo-institutional theory to analyze how institutional pressures affect the implementation of infrastructure public-private partnership (PPP) projects. In this paper, the micro-dynamics through which actors enact responses to institutional structuration in the expansion and transformation of an airport from a public entity into a PPP in Saudi Arabia is investigated.
\end{abstract}

Design/methodology/approach-A single case study design is wellsuited to the exploratory and inductive nature of the research. This method offers an empirically rich and thick description of events, such as the dynamic processes, practices, and types of institutional work carried out by actors and organizations to deliver the project under investigation.

Findings-The case analysis shows that religious symbolic work as social integration triggered system integration work, which expanded the power capabilities of individual actors leading the project. Repair work then followed to alleviate the negative effects of disempowering the agency of actors negatively affected by the PPP model, and to streamline the project implementation process.

Originality/value- The paper contributes new insights regarding the roles of religious symbolic work, allied with social and system integration of power relations in implementing PPP projects, and suggests a theoretical shift from fields to individuals as enablers of new forms of project delivery that break with the institutional status quo. 


\section{Introduction}

An emerging trend in the public-private partnership (PPP) literature adopts neo-institutional theory to analyze PPP projects' implementation (Agyenim-Boateng et al., 2017; Jooste \& Scott, 2012a). While researchers have long emphasized the influence of institutional environment on performance of infrastructure projects (Clegg, 1989, 1990; Kadefors, 1995), this recent emphasis points out that projects do not operate as "lonely islands," but are "contextually-embedded open systems" that function within complex organizational and historical settings (Engwall, 2002, p. 790). The institutional approach thus encompasses the past experiences, values, and social norms that underpin project organizing (Hodgson \& Cicmil, 2007; Kujala et al., 2014; Soderlund, et al., 2017). Morris and Geraldi (2011) have stated that a focus on the institutional level can "improve the performance of projects" because their technical and strategic features are "conditioned, constrained and supported" by their institutional milieu (p. 28). In this paper, PPPs are defined as "long-term contracts or arrangements" in which the private sector is "involved in the design, building, maintenance and/or operation of a public infrastructure," which it co-finances (Koppenjan, 2008, p. 1991). Furthermore, institutions are defined as "regulative, normative, and cultural-cognitive elements that, together with associated activities and resources, provide stability and meaning to social life" (Scott, 2014, p. 56). They are the "shared rules, beliefs and practices...enacted and (re)produced by various actors" within various organizations (Tukiainen \& Granqvist, 2016, p. 1835), mutually constituting their institutional universes.

A review of the PPP literature adopting neo-institutional theory reveals two central themes: 1) the impact of external isomorphic pressures on the choice of PPP for infrastructure delivery; and 2), the role of PPP-enabling organizational fields and structuration in facilitating PPP implementation. As such, by focusing on macro and meso levels of analysis, these bodies of literature have ignored "what happens inside the black box of megaprojects" (Söderlund et al., 2017, p. 9), and this leaves unexplored the agentic and power dynamics through which the interplay between individual actors and their institutional structures occur (Lawrence, 2008). Overcoming this gap requires exploring the micro-dynamics and power relations through which actors affect their institutional environment (clegg, 2010). However, research regarding how actors use power to shape organizational life and projects remains scant despite its centrality to understanding the interactions between the work of 
individual actors and the constraining forces of institutional structure (Clegg, 2010; Rye, 2015).

The paper neither overstates macro-institutional effects on projects nor overlooks the micro perspective. Instead, it attempts to strike a balance between them and argues that departing from the micro-level might enable us to capture actors' actions and reveal their strategies as they urge other actors to support their ideas (Lawrence et al., 2013). To achieve its objective, this paper adopts the approach of institutional work defined as "the purposive action of individuals and organizations aimed at creating, maintaining and disrupting institutions" (Lawrence \& Suddaby, 2006, p. 215). Because this framework allows a micro view of the activities and strategies of institutional actors and portrays them as "reflective, goal-oriented and capable" agents, it can potentially uncover the tactics actors use to acquire and use power to affect existing forms of project organizing (Lawrence et al., 2013, p. 1024). As such, the two central research questions of this study are: 1) What types of institutional work do individual actors perform to gain power to initiate PPPS, and 2) how do the resultant modes of power drive the implementation process forward?

We investigate these questions in the context of Saudi Arabia, which is a suitable empirical setting in which to answer this question because PPPs have not been the institutionalized or legitimate form of infrastructure delivery in the past. When the extension of Medina Airport was privately financed and then transformed from a public entity into a private one in 2012, PPPs entered the scene for the first time in a transportation project. Exploring how individual actors managed to implement such a divergent organizational change and navigate institutional structures to implement new forms of projects is the story we recount and analyze.

In doing so, we advance neo-institutional theory and project management in three significant ways. First, we expand the means through which institutional work affects institutionalized forms of project organizing. We propose that religious symbolic work, as a specific form of institutional work in which actors purposefully employ shared religious beliefs to influence the decision-making of powerful actors who can enable and empower the implementation of new forms of project organizing. Second, we broaden the analysis of organizational power in projects and show how power can be a positive force for change when triggered by religious symbolic work. Finally, we stress the importance of a theoretical shift from fields into micro activities of individuals, and we analyze 
the interplay between agency and structure to produce analytical insight into the lives and actions of agents inside projects.

The paper is organized as follows. First, a literature review discusses recent uses of institutional theory to explain the implementation of PPP projects and illustrates the lacuna of a micro-perspective. The institutional work approach is presented together with the reasons why it can provide deeper insights into how actors can exploit existing symbolic and power dynamics to affect the existing institutional structure. The case design, data-gathering and analysis techniques follow before the presentation of research findings. Finally, the paper's theoretical contributions are discussed.

\section{The impact of institutional context on PPP projects}

The following section reviews the evolving and disparate body of research that explicitly uses the label of "institutional theory" to analyze which factors affect the adoption and implementation of PPPs. This section argues that while the public and project management disciplines have employed several conceptual lenses such as isomorphism, organizational fields and structuration to explain why governments choose PPPs instead of traditional forms of project organizing, these lines of research have not incorporated the micro-level analysis that can reveal the institutional work of actors in affecting the choice and implementation of projects.

\section{Isomorphic pressures and adoption of $P P P$}

When academic research often reports political controversies (Khadaroo, 2005; 2008; Flinders, 2005), technical complexities (Zhang, 2005) and higher risks and uncertainties muddling the implementation of infrastructure PPPs (Grimsey and Lewis, 2000; Stafford and Stapleton, 2017), not to mention their dubious claims of value for money and efficiency gains (Carpintero and Petersen, 2015; Biygautane, 2017), why do governments continue to adopt PPPs?

Neo-institutionalism's "explanation of the similarity ('isomorphism') and stability of organizational arrangements" offers a useful framework to answer this question (Greenwood and Hinings, 1996, p. 1023). Countries' adoption of PPPs can be ascribed to the interplay among several isomorphic pressures operating either within or outside these countries' institutional contexts, forcing these countries to imitate existent practices within their institutional fields to acquire and sustain their legitimacy (Scott, 2008). For example, Khadaroo (2005) has 
attributed the emergence of the UK'S PFI standard-setting process to three factors: coercive pressures exercised by the UK's Treasury, normative pressures stemming from the accounting profession, and mimetic forces that saw public sector organizations plagiarizing each other's submissions to the Treasury. Similarly, Connolly et al., (2009) have found that, despite the certainty of government actors in Ireland that PPPs would not offer higher value for money as propounded by PPP enthusiasts, "indications from the UK government that PPP was the only game in town" meant that it became "the only option" for delivering school infrastructure (p. 10). The same study revealed that, while Ireland's local government knew about the "negative aspects of PPPs in the UK," they still "persisted with the PPP model and sought legitimacy through its adoption" (p. 12) .

A recent study by Sheppard and Beck (2016) has contended that, while Ireland's central government originally introduced the UK's PPP model as a voluntary option to modernize its public administration, it is now increasingly pushing the adoption of PPPs for infrastructure delivery. Ireland's public-sector organizations are now reported as reluctantly pursuing PPPs to maintain institutional legitimacy (Sheppard and Beck, 2016). Moreover, Jooste, Levitt, and Scott (2011) have found that mimetic pressures explain the diffusion of infrastructure PPPs from the UK into British Columbia (Canada), Victoria (Australia), and South Africa. Several actors from those countries traveled to the UK to learn from its PFI model or hired consultants with such experience in order to replicate the UK's example.

\section{Organizational fields and structuration}

As a result of cancellations of several contracts for high-profile PPP projects (Jooste and Scott, 2012a) as well as reports of their failure to deliver the promised value for money (Connolly et al., 2009), isomorphic pressures for adopting PPPs were insufficient to explain why governments adopt them or why PPPs ultimately fail in these cases. Many PPP scholars, therefore, have responded to this situation of apparent failure by adopting organizational fields as a unit of analysis to examine how certain organizations could support or hinder PPP programs. Organizational fields are "in the aggregate, constitute a recognized area of institutional life: key suppliers, resource and product consumers, regulatory agencies, and other organizations that produce similar services and products" (DiMaggio and Powell, 1983, p. 148). The field perspective enables a shift from "an organization-centric or dyadic to a more systemic level of analysis," which captures not only "organizations in environments but ... the organization of the 
environment" (Scott, 2008, p. 434). Fields thus serve as an intermediate layer between the internal dynamics of PPPs and the broader social context. Jooste and scott (2012b) have stated that the complexity of PPP projects requires developing an institutional field: they nominate the capacity of public sector organizations, increasing $\mathrm{PPP}^{\prime} \mathrm{s}$ legitimacy, and balancing the interests of the public, private, and civic sectors as key issues in its establishment. Such requirements, they suggest, can be provided only through "PPP-enabling organizational fields," which include sponsoring departments, PPP units, transaction advisors, regulators, advocacy associations, and development agencies (Jooste and Scott, 2012b, p. 22).

Several comparative studies have, consequently, begun to examine the significance of PPP-enabling organizations. Mahalingam et al., (2011) have suggested that the effectiveness of coordination agencies (PPP units) increases when they are involved in the entire project cycle, especially if they ensure the transfer of PPP-related expertise to government departments. Jooste and Scott (2012a), however, have argued that a stand-alone PPP unit is insufficient. Instead, when groups of public, private, and notfor-profit entities work together, they exert a stronger impact on PPPs' implementation. More recent studies confirm this claim while listing government strategies that effectively translated into increased adoption of PPPs in Ireland (Sheppard and Beck, 2016). Nonetheless, Verhoest et al., (2015) question the full impact of PPP-enabling organizations on PPP projects and found that, while organizational support for PPP was necessary, it was insufficient to account for greater uptake of PPPs.

While the organizational fields' perspective sheds light on how organizations affect projects' implementation, this stream of research has been complemented by the work of PPP scholars who have recently adopted the structuration perspective to provide a bigger picture regarding how the socio-political features and blueprints of their institutional contexts are carried out in PPPrelated fields (Scott and Levitt, 2017). Structuration theory states that social structures contain organized rules and resources that "are not brought into being by social actors, but continually recreated by them via the very means whereby they express themselves as actors (Agyenim-Boateng et al., 2017). In and through their activities, agents reproduce the conditions that make these activities possible" (Giddens, 1984, p. 2). As cases in point, Jooste, Levitt and scott (2011) have analyzed why although governments in Australia, Canada and South Africa all gained insights from the "the UK's Private Finance Initiative (PFI) as a first 'PPP-enabling field' and an exemplar for other countries," 
their PPP-enabling fields ended up evolving differently (p. 12). By investigating the roles of several PPP-related organizations within the three countries, the activities of central institutional entrepreneurs in structuring their organizational fields, and the mechanisms actors adopted to create PPP-enabling mechanisms, the authors confirmed structuration theory's assertion that actors "bring about the formation of the field and change in it over time" (p. 22) in a manner that reflects prevailing political and social preferences.

Likewise, Mahalingam and Delhi (2012) have examined why PPPenabling fields evolved differently in three similar Indian states that experienced the same coercive pressure from their central government to adopt PPPs. They concluded that, when the actors viewed PPPs as being aligned with their own interests, they formulated PPP-supporting organizational fields. In contrast, those that saw their interests threatened by the PPP model designed PPP-opposing organizational fields. The findings of this article direct attention toward the "agency of field actors" (p. 183) and reinforce the premise that organizational fields are subject to change or continuity based on the interests and capacities of field actors. Furthermore, Matos-Castaño et al., (2014) traced the reasons why PPPs' requirements, such as capacity, trust, and legitimacy, were successfully diffused in the organizational field of the Netherlands but failed to materialize in India. They found that since PPPs fit the political and social expectations of policymakers in the Netherlands, those actors institutionalized the required mechanisms to support PPPS' implementation. The lack of such interest among policymakers in India was behind the absence of similar supporting mechanisms and led to a decline of PPPs. While these studies offer valuable insights regarding how organizational fields affect PPPs, they overlook the types of institutional work that occur at a more micro-level within these fields.

To summarize, the role of individual actors has not been incorporated into the PPP debate. In contrast, the extant literature's focus on isomorphic pressures, organizational fields and structuration limit the scope of the PPP debates to how the "activities and interactions of a set of organizations" determine PPP project implementation outcomes (van den Hurk and Verhoest, $2015, p .4)$.

Institutional work and the micro-dynamics of individual agency 
In this section, we suggest that connecting existing PPP research -that currently adopts a meso level of analysis- with the institutional work perspective can potentially uncover the role of actors' work in PPP projects and provide the missing micro-level of analysis in PPP literature. Specifically, this section borrows recent insights from neo-institutional theory and power literature to reveal the strategies and symbolic work employed by individual actors to access and use power to change institutionalized practices.

\section{Institutional and symbolic work}

Institutional work is "the purposive action of individuals and organizations aimed at creating, maintaining and disrupting" institutional norms and rules that govern organizations (Lawrence and Suddaby, 2006, p. 215). It portrays individual actors as autonomous centers of action in institutional fields. Institutional work acknowledges that individual agency is neither the outcome of actors' institutional embeddedness, nor is it immune to its influence. Instead, individual actors are endowed with the capacity to reflect on their institutional surrounding, "develop conscious intentionality," and plan strategic actions and activities to "affect their social symbolic context" (Phillips and Lawrence, 2012, p. 223). Institutional work begins by exploring why (intentionality) and how (effort) actors purposefully engage in both the practices and processes of organizational or institutional change, regardless of whether or not they accomplish their goals. Starting from the why and how is important, since this can address structuration theory's silence concerning how actors' knowledge and awareness of their context develops, which micro-activities they adopt and how any resultant conflicts or tensions between individual agency and structural controlling mechanisms play out (Lawrence and Suddaby, 2006).

Numerous studies have examined the forms of work actors engage in to create, maintain or disrupt institutions or institutionalized forms of organizing (Lawrence and Suddaby, 2006). This type of work requires the mobilization of material as well as cognitive resources and efforts to establish the legitimacy of the proposed change (Johnson, 1990), and convince actors for the need of abandoning an institutionalized practice that no longer fits organizational life (Maitlis, 2005). One of the effective strategies for changing institutionalized practices is sensegiving (Fiss and Zajac, 2006), defined as the "process of attempting to influence the sensemaking and meaning construction of others toward a preferred redefinition of organizational reality" (Gioia and Chittipeddi, 1991, p. 442). Sensemaking is particularly 
essential when actors within an organization face surprising or confusing situations that emanate from an abrupt change of organizational direction or strategy (Gioia and Thomas, 1996).

Furthermore, work related to readjustment of organizational identity (Bailey and Raelin, 2015; Kraatz et al., 2016) has been featured in organization studies literature as an important strategy to restructure the organizational culture of entities undergoing change and to fit the new realities of working with different logics (Ravasi, 2016). This work aims to "reduce the tensions internally between its organizational identity and the new practices associated with the new logic" (Gawer and Phillips, 2013, p. 1057), requiring several activities and strategies, ranging from material and moral incentives to educating actors and building their capacity and readiness for change (Bailey and Raelin, 2015; Lawrence and Suddaby, 2006).

Institutional theorists, however, have noted that organizations are not merely technical systems governed by rational decision making, power dependencies, and actors" interactions, but most importantly, organizations carry "symbolic aspects." (Scott, 1987, p. 507; Dandridge et al., 1980; Turner, 1990). Organizational symbolism refers to the "discrete acts of persuasion or influence," which emanate from actors' shared belief systems and which are embedded within their social and cultural background (Hambrick and Lovelace, 2018, p. 111). Organizational actors activate these symbols "to reveal or make comprehendible the unconscious feelings, images, and values" that are shared among members of an organization (Dandridge et al., 1980, p. 77), in order to "propel" certain actors to "engage in behaviors that align with the exhilaration they derive from the symbol itself" (Hambrick and Lovelace, 2018, p. 118; Strati, 1998).

The institutional work literature has recognized the significance of symbols in organizational life and begun to ascribe particular interest in "symbolic work that uses symbols, including signs, identities and language" to affect an institutional order (Hampel et al., 2017, p. 570). The breadth of these symbols is limited, however, to the use of language and narrative rhetoric (Zilber, 2007), identity and practice work (Gawer and Phillips, 2013; Jones and Massa, 2013), emotion work (Watson, 2008; BarberáTomás et al., 2019), aesthetic work (Warhurst and Nickson, 2007), or more recently how social symbolic work affects institutions (Lawrence and Phillips, 2019). At its essence, symbolic work entails using "specific framing language that fits better with [actors'] divergent stakeholder preferences" (Fiss and Zajac, 2006, p. 1173), and persuading actors to support a particular 
organizational form over current ones. Yet, scant attention has been paid to the role of religion in affecting organizational actors' work in organization studies (Tracey et al., 2014).

Although the use of symbols has been thoroughly examined in organizational studies, analysis of how associating symbolic meanings with mega-infrastructure projects contributes to their successful delivery is very limited (Soderlund et al., 2017). Existing studies have primarily focused on how political symbols advance projects (Van Marrewjk, 2017). For example, Rego et al., (2017) argue that the timing of constructing or completing three necessary historical megaprojects in Brazil was driven by the political and symbolic importance of events such as FIFA 2014, which played a critical role in finishing one of those projects on time. Similarly, van der Westhuizen (2017) provides a compelling analysis of how megaprojects as political symbols can be successfully implemented when they are closely associated with mythical discourses. The first high-speed train in South Africa gained the needed political support because the promoters of the project demonstrated the hosting the World Cup in South Africa depended upon the construction of that project to market for hosting the global sporting event. Similar to organizational studies' literature, projects' religious symbolic meaning, or how actors use religious symbols to affect projects' implementation, has not been addressed in project management literature either.

Actors' initiatives to carry out institutional work and introduce organizational practices that diverge from the status quo encounter resistance from both the invisible pressures of isomorphism embedded within an institutional field, and the individuals and organizations directly affected by any proposal for changing the status quo (Clegg and Kreiner, 2013). Hence, in order to fully understand how actors use symbolic work to change organizations, it is essential to integrate an analysis of power dynamics within organizations. The lens of power will help uncover how institutional work undermines controlling effects of structure, and through which types of work individual actors' agency overpowers the constraining pressures of structure (Rye, 2015).

\section{Institutional work and power}

Institutional theory's overemphasis on isomorphism resulted in the "element of power ... [being] largely absent from engagement with DiMaggio and Powell's work" (Clegg, 2010, p. 5). As Lawrence (2008, p. 175) has argued, most of the subsequent research based on DiMaggio and Powell's seminal work examined how the choices of 
actors or organizations were influenced by certain isomorphic forces within their institutional fields "left out an explicit consideration of power" that would describe how actors are obliged to do what they would not do otherwise (Lawrence, 2008).

The concept of power is complex and elastic, and its definitions vary depending on the field. In this research, the examination of power is narrowed down to its conceptualization within the organizational studies literature (Clegg, 1989; Lawrence et al., 2001; Lawrence et al., 2005), which defines power as "a relational effect, not property that can be held by someone or something" (Clegg and Kreiner, 2013, p. 270). Based on this definition, power is only explicit when it is exercised through relationships among actors and organizations (Clegg, 1989), manifested in the ways that "the behaviors, attitudes, or opportunities of an actor are affected by another actor, system, or technology" (Lawrence et al., 2012, p.105).

In the organizational analysis, power is postulated as operating through two modes: "episodic" and "systemic" (Lawrence et al., 2001; Lawrence and Robinson, 2007). Episodic power consists of the "relatively discrete, strategic acts of mobilization initiated by self-interested actors," and represents the most explicit expression of the agency of specific and recognizable individual or organizational actors (Lawrence et al., 2001, p. 629). Systemic power, meanwhile, operates "through the routine, ongoing practices of organizations" and is embedded in the cultural and "social systems that constitute organizations" (Lawrence and Robinson, 2007, p. 384). Hence, this mode of power is not attributed to specific individuals but is coded within overarching cultural and organizational systems.

To better articulate how these two modes of power function in a social context, Pitkin's (1972) concept of power over is used to describe systemic power, while we use power to in reference to episodic power, appreciating that power episodes do not necessarily have to be coercive or constraining, but could also be facilitative. Power over means power "over other people, [or] enforcement of one's intentions over those of others," while power to means "an ability to do or achieve something independent of others," including indirectly through routine and bureaucratic ways (Göhler, 2009, p. 28). As such, power over constantly restricts the choices of those subjected to it, "disempowers" their capacity, and limits their fields of action (Rye, 2015). The focus of power to, in contrast, is not on its effect on others subjected to it but on its "empowerment" of other actors to act more autonomously and to gain a comparative advantage over other actors 
in the field. Sometimes this is achieved in order to overpower the agency of others; other times it may conjoin with others to expand collective agency. The delicate interconnectedness between power over and power to means that, in order to access power over, actors need the capacity to exercise power to; however, exercising power to do something is also dependent upon having access to power over resources and people (Clegg and Kreiner, 2013).

How are these modes and circuits of power used and how do they affect actors and organizations? Lawrence et al., (2001) have argued that when actors use episodic power and approach their targets as subjects with the capacity to choose whether to do something (Clegg, 1989), they use influence to persuade them of the benefits of a certain action. Influence is carried out through informal networks and relies on persuasive accounts and negotiations that are particularly important to justify why a new trajectory or organizational model is essential, making this form of power particularly useful during the starting phases of new initiatives (Lawrence, 2008). However, when organizational actors are treated as objects (incapable of choice), force is applied coercively through formal organizational hierarchies to leave them no choice but to do something that they would not otherwise do, either because it does not serve either a personal or organizational sense of their interests (Lawrence and Robinson, 2007). The two are often entangled, of course, one is the bearer of the other.

Although systemic power may be empirically invisible, manifest through tacit pressures on actors and organizations, it differentially affects actors when they are considered as either subjects or objects. When actors are treated as subjects, social power is exercised as discipline, which "shapes the identities of targets and...leads them to act in specific ways," and subsequently and indirectly affects the choices that those actors make (Lawrence and Robinson, 2007, p. 389). However, when actors are treated as objects, systemic power is manifested as a mode of domination that indirectly restricts choices through informal representations of systemic power in the guise of culturally taken-for-granted practices, as well as more formal representations, such as the controlling effects of bureaucratic systems in which the actors operate (Lawrence, 2008).

Furthermore, while earlier theorizations of power considered power relations as having a one-dimensional coercive perspective whereby one actor determines the choices available for another actor (Dahl, 1975; Lukes, 2005), Clegg (1989) argues that power relations are multi-dimensional and operate through three 
different and interconnected "circuits of power." The first circuit of power is episodic, and it represents the agency or micro-dynamics of action which individual actors adopt to either constrain a certain action or to enable it, which results in resistance or support of affected actors (Major et al., 2018). The second circuit of power is dispositional which enables actors to reinterpret the rules within an organizational field, and it is exercised within a system of social integration whereby actors within a social system use shared meanings to justify and achieve their objectives (Clegg, 1989; Major et al., 2018). The third circuit of power is facilitative and is exercised through system integration which entails reshaping or changing the routines and rules within an organizational setting to fit actors' interests and objectives.

While these forms of power are well-documented in the organizational analysis literature, what is unclear is the type of institutional work that triggers systemic power and in turn, legitimizes new forms of project organizing and how actors build upon this emerging power to implement projects. This paper investigates the role of episodic power to "initiate change by advocating key ideas and persuading actors to experiment with new behaviours" (Lawrence et al., 2011, p. 109), while also examining how social and systemic power is exercised over existing regulatory and bureaucratic structures to empower and enable individual actors to carry out their work.

\section{Methodology}

\section{Research Context}

Saudi Arabia is a context in which public procurement has been the only institutionalized method of infrastructure service delivery over the past 70 years (Biygautane, 2017). The existing legal and regulatory frameworks have been incompatible with the requirements of complex PPP contracts. The Government Tenders and Procurement Law (GTPL) that governs tendering of infrastructure projects did not allow private finance for public infrastructure, or possess the flexibility required for designing PPP contracts (Ashurst, 2013). Furthermore, the normative pressures for global diffusion of PPP projects do not exist in Saudi Arabia. High government revenues from oil exports have meant that financial constraints driving Western governments to private finance did not exist in Saudi Arabia, nor were the promises of higher efficiency and value for money important either, as the overall bureaucratic system in the country did not prioritize efficiency or innovation in service delivery (Ali, 2010). The bureaucracy was rather an accommodation 
for local talents that might not flourish in more exposed and less sheltered environments.

Particular patterns of institutionalization have flourished in infrastructure projects in this context. The construction sector in Saudi Arabia is tightly dominated and controlled by powerful business families with extensive networks of patronage, positioning them as the government's preferred bidders for large contracts (House, 2013). Foreign investors and bidders are disadvantaged when competing for government contracts and corruption is endemic in the construction industry (Al-Riyadh, 2013; Ali, 2010). As such, the lack of effective mechanisms for monitoring the accountability and transparency of the construction sector result in many cases of exploitation of public finances, extensive delays, and incomplete projects (Al-Riyadh, 2009).

\section{The case of Medina Airport}

Medina Airport represents a case of divergent organizational change for two reasons. First, the airport had operated under the government's umbrella since 1972 (IFC, 2012), and the choice of a build-transfer-operate (BTO) contract to expand and operate the airport meant disconnecting from the public sector template and abruptly introducing the untested market ethos. It was a shift that would affect not only the technical operations of the airport but also its identity and organizational culture by forcing a drastic change in how employees and management of the airport had worked for decades. Second, extending the airport through the BTO contract meant the involvement of private finance, which would require new legal and administrative requirements that the Saudi bureaucracy was unprepared to provide.

The successful execution of this mega-infrastructure project in such an institutional environment promises to uncover several empirical and theoretical insights about how power affects projects. It meant that the actors leading the project's implementation had to manage resistance from private actors that dominated the construction sector, public organizations that did not understand or believe in the need for PPP at the airport. Importantly, it would explain how the resistance of the airport staff was managed when they were forced to become private sector employees rather than bureaucrats accommodated in an organization indifferent to commercial pressures.

\section{Research design and data collection}


A single case study design is well-suited to the exploratory and inductive nature of the research (Yin, 2014). This method offers an empirically rich and thick description of events, such as the dynamic processes, practices, and types of institutional work carried out by actors and organizations to deliver the project under investigation (Lawrence et al., 2009), which would otherwise be difficult to observe through quantitative methods. It captures complex processes over time, enables researchers to identify key actors and investigate how events develop, allowing for an immediate reframing of questions as unexpected information emerges through interviews (Eisenhardt and Graebner, 2007).

The data collection techniques used to answer our research questions were commensurate with the chosen case study design. The research relied on face-to-face, semi-structured interviews ranging from 40 to 90 minutes in length conducted with key interviewees who were directly involved in the project implementation process. We conducted purposive sampling (Lincoln and Guba, 1985), aiming to cover a diverse type of actors occupying different roles as first contact interviewees. Therefore, we explored Saudi news articles and published government and private sector reports to identify the names of actors who played a central role in the project. We then relied on our social networks to gain access to these interviewees, and a snowball technique was adopted later on by asking our initial interviewees to recommend further actors who leveraged influence in project implementation (Lincoln and Guba, 1985).

In total, twenty-one face-to-face interviews were conducted by the first author in the Saudi Arabian cities of Jeddah, Medina and Riyadh. To ensure that many voices were included, to minimize retrospective bias problems and to confirm the reliability of the data (Yin, 2014), individuals from across different levels of the hierarchy and various sectors were interviewed. Among the interviewees were five senior government officials, including a previous chairman of GACA and the GACA PPP Team leader who played the role of a project champion. We also interviewees three senior representatives from the private sector including actors from Medina Airport. The interviewing sample also included six senior legal and financial consultants who were instrumental in designing the BTO contract shared important insights about the process of gaining high-level approvals to sign the project contract. Three engineers who worked in the airport before and after its transformation to PPP were interviewed to provide insights about how employees reacted to change in the management of the airport. Additionally, a senior representative of Saudi Airlines provided insights regarding the impact of the airport transformation on the management of airlines. Finally, two senior representatives of an 
international organization in Riyadh who were involved in the process of initiating and implementing the PPP project shared important information about the governance mechanisms that supported the project. The interviews were recorded (except in three cases where extensive notes were taken) and transcribed verbatim.

The interviews were conducted between March 2016 and August 2017, with three supplementary interviews carried out in Riyadh in August 2019. The semi-structured approach that was adopted during the interviews allowed flexibility in asking interviewees the same set of questions, but also asking further elaboration and follow up questions when new themes or insights emerged during the interviews. Generally, our interview questions focused on three themes: 1) reasons why PPP model was used for this project; 2) which actors and organizations enabled the project implementation; and 3) the reactions of employees and management of the airport and how that affected the process of transforming the airport from a public to a private entity. These themes were developed based on our prior familiarity with the research context and its unsuitability with the PPP model, and hence our focus was to understand which actors played a central role in its implementation.

The second source of data was archival data which was important to triangulate the interview findings with more objective analyses of the factors supporting the project (Lofland and Lofland, 1995). Government and consultancy reports, speeches by the Saudi Monarch -discourses of some importance in an autocracy- as well as newspaper articles, were also used. While the total of 41 documents covered mostly the political, legal and regulatory factors affecting the project, broader academic resources were also drawn upon, which covered the normative and cultural-cognitive aspects of Saudi Arabia. Furthermore, we have read and analyzed a YouTube video where Medina Airport employees protested against forcing them to transfer to the private sector and implored the King of Saudi to help them maintain their government jobs, were analyzed (YouTube, 2015), as well as Arabic blogs where these employees shared either their fear or enthusiasm about the transformation of the airport into a private entity. These blogs were crucial given our inability to access a larger number of airport employees despite our attempts to do so.

\section{Data analysis}

Data analysis was conducted through four stages following a deductive and inductive approach congruent with common practice in qualitative studies (Yin, 2014). The first step in our analysis 
was to sift through the data and read interview transcripts alongside secondary sources to develop a comprehensive understanding of how key events, activities, and project milestones evolved chronologically and led to the airport's transformation. We organized this information to guide our analysis, and then sifted through our interview data to identify and code motivations (intentionality) of actors who triggered and pursued the PPP idea and their reasons for its advocacy. At this stage, NVivo 11 was used to conduct systematic analysis and assess the empirical prevalence of emerging analytical themes.

Second, open coding was applied to the interview data (Van Maanen, 1979) to identify the types of institutional work to gain the power to expand and operate the airport on a PPP basis. specifically, we sought for instances and arguments used by individual and organizational actors who were promoting the PPP model and how they justified its need and relevance for the airport project. We sought guidance from institutional work as well as power literature to identify the types and modes of power and their relational impact on actors. Initially, we found that institutional work representing instances of episodic power carried out by the chairman of GACA and head of the IFC office to influence and persuade political actors of the importance of the PPP model for the airport. Their arguments were coded into firstorder themes (Gioia et al., 2013), and we identified "considerable delays face expanding the airport through EPC"; "arguing that facilitating pilgrims" journeys to visit the two Islamic holy mosques of Mecca and Medina is duty of Saudi Arabia towards Muslims" and "using PPP to increase the airport's capacity meant more landing slots for airlines and higher numbers of pilgrims."

Third, we performed axial coding (Strauss and Corbin, 1998), with the team going back and forth between theory and data to collapse first-order concepts into broader second-order theoretical categories and themes. Our purpose was to transcend the descriptive statements from our data and establish more consolidated themes. For example, consistent themes emerged such as "project's religious significance", "political actors with religious obligation" and "religious tourism".

Fourth, and final stage of analysis was to look for aggregate theoretical dimensions, guided by our readings of literature about symbolism and power. We used the label religious symbolism work as social integration to categorize the episodic power represented by efforts and justifications used by actors to influence and activate political interest in the project. Such religious symbolic work was the bedrock to their commitment that the PPP model was the 
only practical solution to deliver the project successfully, and emphasized the religious symbolism that the project signified as enabling Muslims to access the holy mosques of Medina and Macca. This form of symbolism has not been revealed in existing project management nor institutional theory.

The same analytical method was used to search for instances of systemic power and its manifestations. However, it was important first to understand the bases of such power and how it was accessed or activated by the two actors initiating the project, as well as the arguments they used for each individual/organization to which they reached out. The research then sought out how systemic power led to the empowerment of the PPP project, and how this altered the institutionalized and routinized ways in which the saudi bureaucracy administered infrastructure projects. It was found that systemic power had two functions. First, a Royal Order acted as the dispositional form of power (Clegg, 1989) that established the political legitimacy and urgency of delivering the project on a PPP basis. A Royal order is an exceptionally strong mandate of social integration in saudi society, governed as it is by an absolutist monarchy. Second, ministerial power freed the PPP project from regulatory and bureaucratic controls that might otherwise have blocked its implementation, while the "professional disciplinary power" of the PPP Team Leader streamlined and supported the system integration of the entire implementation process (Table 1). We labeled this type of institutional work "system integration work" which represented the systemic form of power.

After identifying the types of work to access power, we then moved to how the resultant forms and modes of power were used to force the implementation of the PPP project. It was clear to us that the empowerment of the PPP project meant the immediate "disempowerment" of the agency of several individual and organizational actors. We found that this type of power stripped the project from out of the hands of local private actors, altering how the bureaucratic system administered projects, with a considerable impact on how individual actors worked at the airport. We labeled this type of work as "work to disempower the agency of resisting actors".

We then focused our analysis on identifying the coercive consequences of systemic power for these actors and the type of work conducted by GACA and the winning consortium to alleviate the effects of forcing the PPP project on the institutional structure. We identified repair work as the form of institutional work that comprised several activities such as sensegiving (Gioia and 
Chittipeddi, 1991), capacity building, identity work (Bailey and Raelin, 2015; Gawer and Phillips, 2013) and persuasion, which we derived from the broader literature of institutional work and emerging themes from our data. This information is synthesized in Table 2 .

Finally, we developed a comprehensive data structure (Figure 1) to theorize the relationships between themes and aggregate dimensions, and most importantly to develop a process model (Figure 2) that demonstrates the recursive relationships between the types of institutional work and different forms of power, and how they affect project implementation processes.

\section{Figure 1 about here----}

\section{Findings}

We begin by demonstrating why GACA (a typical saudi government entity) decided to break away from the institutionalized form of project delivery and tout PPP as an effective method for expanding and operating its airport (intentionality for institutional work), rather than using the highly institutionalized and traditional public procurement model. Then, we present the institutional work (effort) that they conducted to acquire power, and how that power was used to drive the implementation process forward.

\section{Prologue: Trigger and obstacles}

Familiarity with market-like practices. The empirical findings revealed that, although GACA was a government instrumentality embedded in Saudi bureaucratic inertia, its top leadership endeavored to instill market-like practices internally. GACA's newly appointed leadership had extensive experience working in the business sector, and aimed to apply this experience within GACA by improving the quality of its airports, enhancing customer services and satisfaction, eventually to corporatize and privatize airport assets. As a former chairman of GACA stated, "Saudi is a very difficult place to do business, but I used to say that, at GACA, we could do much better than other government entities." Such objectives, which would seldom be considered seriously in other Saudi government departments, guided GACA to greater engagement with the private sector in delivering services through competitive bids. A senior official at IFC said, "I think GACA was one of the leaders among the government entities in saudi in terms of outsourcing its activities and working with the private sector and that was owing to its strategy to bring the private sector to the aviation sector." One private-sector consultant stated that GACA 
had developed the internal capacity to "design and develop projects that were output-based with specific deliverables, rules, KPIs, and requirements, and asked the private sector to bid on that basis."

GACA's active engagement, trust, and learning from the private sector has grown through several small-scale projects. The first experiment in collaborating with the private sector was in December 2006, when GACA awarded a 20-year BTO concession contract worth \$249 million for the modernization and operation of Hajj Terminal in Jeddah to a consortium led by the Saudi conglomerate Bin Laden Group (IFC, 2013; Fenton, 2010). One senior IFC official asserted, "we had so many difficulties and there was no system and no understanding of PPPs, but it worked out. It was not the best example, but it was the first experience." A BOT contract for the same airport was awarded to a private consortium to develop its water desalination plant (IFC, 2010). In those projects, GACA "conducted testing of the local private sector's capacity to deliver such a project in the market," as explained by the PPP Team Leader at GACA, and this made it realize its strengths and limitations. It was also a valuable learning experience through which IFC and GACA collaborated and studied the challenges and opportunities of Saudi's institutional setting. The former chairman of GACA put it this way:

"In these two projects, we learned a lot about what the other side wanted and how the private sector performed. There were so many lessons we learned from the contractual setup and we went through many challenges that we managed to overcome and learn from."

Technical need and lack of local expertise. The facilities of the Medina Airport had not been refurbished or expanded since its opening in 1972 (Ballantyne, 2011). When the King announced its transformation into an international airport in 2006 (Al-Riyadh, 2006) the airport "was in desperate need of an overhaul to cope with increasing arrivals," which exceeded 3.5 million in 2009 (a 50\% increase from the previous year), "making it the largest increase across all the Kingdom's airports" (Fenton, 2010, p. 2). The airport is a major port of entry for the faithful making the Hajj. The airport management and operation could not cope with passenger growth, which averaged 21\% annually at the time and predicted to reach 14 million by 2035 (Ballantyne, 2011). Although the airport operated year-round, as explained by a private sector interviewee, it experienced "the largest number of passengers for two months each year during the pilgrimage season, and the airport struggled to manage that process efficiently." Due to constrained capacity, considerable international traffic had to be turned 
away, with increasing requests from airlines to obtain landing permits being declined. Furthermore, lack of efficiency and good governance within the airport's old management led to nepotism and treating airlines differently as a representative of a major airline stated:

"...we used to suffer from nepotism, disrespect of the principle customer, preference of some companies over other ones. They were so slow, and they did not provide good services and we complained all the time to airport management, but in vain."

Previous efforts to expand the airport using an EPC contract and local private actors had been unsuccessful. The Prince of Medina presented a proposal to the Council of Ministers in early 2000 s to refurbish and modernize the airport (Ouadou, 2000), but, according to one public employee, this progressed sluggishly due to "the need for a contractor and operator with a proven record of managing and operating complex airport projects...and getting the budget for the project approved by several government entities." In light of GACA's experience with the private sector, such high sophistication in airport construction and management was nowhere to be found in the saudi private sector, and this required looking for alternative solutions internationally.

The comfort of GACA's leadership in working with the private sector, the dire technical need to expand Medina Airport encouraged the IFC head in Saudi Arabia to propose to GACA's chairman the idea of using PPP for the airport. The head of IFC thus explained to the GACA team the idea behind PPP and shared successful cases of international airports that were constructed and being operated under the PPP scheme in Jordan, Turkey, India, and Europe. Such isomorphic and mimetic pressures from international and regional experiences of PPPs provided a strong ground for suggesting and promoting PPPs in Saudi, particularly this promising business case of Medina Airport.

The proposal was welcomed, and the GACA and IFC teams then engaged in sensemaking exercises to analyze the requirements for translating the PPP idea into actual practice. Several meetings were held between the teams to discuss the technical aspects of the project and form a group of advisors and experts who would examine the prospect of operating Medina Airport through a private company. Part of the sensemaking effort involved commissioning to the IFC the drafting of a comprehensive feasibility study, which analyzed the practicality of expanding and operating the airport on a PPP basis. The IFC's study showed hypothetical scenarios of the airport's performance under both the public and private sectors. The sophistication of managerial and operational methods 
promised under the private sector's construction and operation of the airport further encouraged GACA to pursue the PPP route. One PPP project specialist commented, saying, "We were very excited about the PPP idea when we saw the new technical and managerial methods and techniques that our airport had not possessed before." The results of the due diligence strategic report were equally promising. The airport was a bankable project due to the rising international traffic and growing demand from international airlines to land. The PPP Team Leader indicated that: "due diligence took us four to five months, and this was the part where we analyzed the financial, legal, and technical aspects of the PPP project, and we found that it was viable and visible."

\section{Religious symbolic work as social integration}

The rigidity of the Saudi bureaucratic systems and lack of regulatory systems to support PPPS convinced the IFC head and GACA chairman that acquiring political power and support were the only means through which project implementation would be feasible. Those two actors then exercised a mode of episodic power that influenced and convinced the top political leadership, on an exceptional basis, to allow the use of a PPP model that promised better outcomes for the airport than the public procurement method.

Arguing that the project's religious significance required an immediate solution. A large number of high-profile projects had in the past been excessively delayed or unfinished in Saudi Arabia, with several past PPP proposals for subway systems and trains never materializing (Shaw-Smith, 2011). However, the airport project had a unique religious status for actors who were approached to support it. As one senior legal consultant stated, "Medina Airport isn't for air transport, it's for Hajj infrastructure." The key message repeatedly emphasized by the IFC head and GACA chairman when resorting to their social and political networks to form a coalition of actors to advocate the project was the religious significance of the project. The airport, as a gateway to the city of Medina, necessitated immediate action to increase its capacity and enable larger numbers of Muslims to perform their pilgrimage. The IFC head took the initiative early on and approached the Prince of Medina to explain the benefits and opportunities of delivering the project through PPP as well the positive impact of religious tourism on the economy of Medina. The Prince accepted the idea, although no airport in Saudi had ever been financed, constructed, or operated by the private sector, but the religious uniqueness of this airport made it a religious obligation to expedite its expansion. An interviewee from the private sector stated that: 


\begin{abstract}
"Madinah Airport represents a different business environment and passenger profile because it is a religious airport. It is not like Riyadh airport, it is not always commercial or operational, and its clients are primarily pilgrims and mainly during pilgrimage seasons."
\end{abstract}

The proposal to expand the airport had been with the council of Ministers since the early 2000s, but its budget decision had yet to be completed, let alone the lengthy process of searching for qualified companies to deliver it. ${ }^{1}$ As a member of the Saudi royal family with considerable political and administrative power and direct access to the King, the Prince's involvement from this early stage was critical. He endorsed the project and informally reached out to other ministers and high-level bureaucrats to advocate it as well. The chairman of GACA easily gained the support of the Minister of Defense for the project, since his organization operated under the umbrella of the Ministry, and he was able to raise the topic at Ministerial meetings. The motivation behind these actors' readiness to support the project stemmed essentially from its religious symbolism. A government sector interviewee stated that:

\begin{abstract}
"Location of this airport in Madinah makes it very special. It is a place where all Muslims want to go to. All Muslims wish to visit Madinah before anywhere else and this airport is their gate to it, and by extending it we will allow more Muslims to perform their religious rituals."
\end{abstract}

Reaching out to political actors with a religious obligation to cater to pilgrims to the two holy mosques. As a part of their effort to build consensus and support for the project, the chairman of GACA and other ministers brought the proposal to expand the airport on a PPP basis to meetings of the Council of Ministers and Supreme Economic Council, which are headed by the King. They all emphasized the duty of Saudi Arabia to facilitate Muslims' pilgrimage, and one government official confirmed this fact by stating that: "Muslims save for years and years to come to Umrah or Hajj and being unable to host them because of the capacity of the airport is our responsibility." Individuals promoting the airport expansion on PPP also cited the due diligence report's findings that showed how expanding the airport and operating it on a PPP basis would increase the number of pilgrims from 3 million yearly in 2008, to 8 million immediately after its commercial

\footnotetext{
${ }^{1}$ In fact, it took 11 years for the project to be started. In October 2011, a consortium entered into a contract with the GACA to build and operate the Prince Muhammad Bin Abdulaziz International Airport in Al Madinah Al- Munawarah under a 25-year concession. In 2018 it had 8,144,790 passengers pass through and 60,665 aircraft movements (source: TAV Traffic Results)
} 
operation, to 18 million by 2035, and up to 40 million in the third phase of expansion in 2050 (Sabq, 2015).

The connection between the religious duty of the King to Muslims and Medina Airport is apparent in his speech in 2006, which announced that, "...given the importance of Medina to the Islamic world and to the entire world, I announce the transformation of Medina Airport into an international airport" (Al-Riyadh, 2006). As such, the religious factor was crucial in approaching the King to support the delivery of the airport through non-traditional means. Many interviewees stated that the connection between the religiosity of the airport and the political support given to it created a firm bedrock for embracing the PPP model, and as a legal consultant stated: Hajj is fundamental to political legitimacy of the Kingdom, fundamental for its responsibility." Another government official also stated that

"...increasing number of pilgrims is a very politically sensitive
matter, it is part of delivering the Kingdom's obligation to the
Muslim Community and it is the responsibility of the Custodian of
the holy mosques, that's what we do as Saudis and that is who we
are"

Demonstrating that religious tourism supports job creation and economic growth. The head of IFC presented the PPP idea to the Minister of Finance and articulated its financial rewards, such as reducing the costs of expanding and operating the airport and expenses of employees, albeit with considerable financial guarantees to be borne by the ministry. The function of the airport as the gateway of the Hajj to the sacred sites of Islam meant that a flow of income was guaranteed, with the sharp increase in pilgrims each year being testament to that. The Minister of Finance supported the project and became an essential member of the coalition of actors who endorsed it, emphasizing its importance at the Council of Ministers and Supreme Economic Council meetings. The economic benefits of the project were highlighted, including drastically increased income flow through better management of landing slots and revenues. The increased volume of passengers that would be visiting the Medina and Mecca mosques would mean a massive increase in the city's economic activities and job creation in the tourism-related industries that formed the backbone of those activities. A private sector interviewee stated that "religious tourism is the reason that it worked in saudi, and now the government is trying to increase the number of pilgrims, so there will be an extensive need for bigger airport infrastructure in the future." A study evaluating the impact of expanding Medina Airport also showed that the city could potentially host one million visitors per month, with its revenues counting as the second- 
highest source of income for saudi Arabia after oil revenues (Ouadou, 2000). This is supported by a management consultant's statement that:

"...if political leadership of this country is committed to their religious duty to host Muslims, how can they increase people if they do not have enough landing slots for airplanes to take all these pilgrims. We needed the standing of government for such mega projects to feed the religious need of the country."

\section{System integration work}

The GACA chairman and IFC head exercised episodic power to try and influence the thinking of key political actors and have them permit a foreign private company to operate the airport. This was something that had never been done before in Saudi Arabia. The outcome of gaining approval was the empowerment of the PPP project through several forms of power through episodic modes of power as well as social and system integration as illustrated in Table 1.

Exempting the PPP project from regulatory controls through ministerial decrees. One key factor that facilitated access to the highest echelons of politics was the support of the Minister of Defense. The systemic power of the Ministry of Defense was manifest in its position as the most potent Ministry in saudi Arabia, with the Minister always one of the closest members of the royal family elected by the King (Kamrava, 2018), a crucial element of social integration. Since civil airports were, at that time, under the Ministry, other government entities could not dispute or otherwise oppose the Minister's support for the airport. The Minister also supported the project by writing letters to any government entities that required additional documents, the lack of which could risk complicating the implementation process. The personal touch of the Minister smoothed the path for the airport. Similarly, the Ministry of Finance's support was a critical factor in the project's success because it assured system integration by issuing financial guarantees in excess of US \$1.5 billion and also assuming liability in the event that the national airline might default on any of its payments, ensuring the project's bankability and making it attractive to the private sector.

\section{---- Table 1 about here----}

The Council of Ministers and the Supreme Economic Council were two powerful entities that represented the tight nexus of social and system integration in the Kingdom. The concentration of episodic power capabilities vested there empowered the actors 
implementing the project. These councils comprised all of saudi Arabia's Ministers and are chaired by the King. They are the obligatory passage point for decision-making. They issued decrees requiring all government entities to collaborate with GAC. Besides, they issued all the necessary documents to finance the project through a private consortium. Finally, they transferred the airport to the private operator when construction was completed. As one senior bank representative explained, the decrees ordering implementation of the project was "an exceptional case because it was a non-government contract". As such, it bypassed all the routinized ways of writing construction contracts and delivering infrastructure projects. Such non-compliance with customary saudi bureaucracy would have been impossible without the support of the system and social integration condensed in these important obligatory passage points.

The empowering of the project through two ministerial councils resulted in the creation of a high-level steering Committee chaired by the chairman of GACA and composed of eminent figures in the political and business sectors. Again, there was a fusion of system and social integration legitimating the steering Committee because of the prestigious figures which it contained. The committee was created and empowered exclusively to make any and all decisions critical to the project's implementation. The committee held weekly meetings where project-related documents were signed, and letters of support provided to eliminate any bureaucratic or regulatory bottlenecks. The work of the committee was also backed up by the Prince of Medina, who issued orders to facilitate any project-related administrative procedures at the Medina governorate. He also ordered all relevant entities to expedite the issuance of licenses or permits related to water, electricity, and other services supplied by the Medina municipality. Royal writ is the highest form of legitimacy any project could achieve. The Royal imprimatur assured the smooth passage of the project through the byzantine bureaucracies of the state.

Establishing the urgency and political legitimacy of the project through a Royal Order. The ultimate representation of social integration and dispositional power, in this case, was the issuance of a Royal Order. The Royal Order epitomized the political support enjoyed by the project as a high-level national priority that needed to be delivered urgently and legitimized the PPP form for its delivery. With a Royal Order, none would dare to be seen to impede the project. Although not directed to a specific organization or individual, the powers embedded in the Royal Order were implicit. Should there be cases of resistance against the 
project, the issuance of the order would achieve consent. The drastic changes necessarily affecting all usual ways of operating national airports and developing infrastructure that the project entailed would not be resisted. Any necessary change in the behavior of individuals and organizations affected by the project came from the highest source of legitimacy in the land and irrespective of how members of organizations might think about what acting in accord with the order entailed, no individual actor could be blamed for the actions they took. They were enacting the Sovereign's will. One senior government official explained that, "when a Royal Order is issued, nobody has the choice to resist or challenge it." The power of the Royal Order removed any regulatory or bureaucratic barriers even before they arose, a fact emphasized by all interviewees. A representative of an international organization stated that when dealing with the government bureaucracy,

"The project did not face any critical obstructions because it had received a Royal order early on... so we had the top-level kind of green light, and all government entities were aware that the project was a priority and had to go ahead."

Empowering the project champion to streamline the PPP project implementation process. Several interviewees stated that their preparatory institutional work was focused on creating coherent internal organizational dynamics to streamline operations and decentralize decision-making. An IFC representative described the PPP Team Leader, who was also leading the internal PPP unit in charge of the project's administrative duties, as "the oil in the gears making sure that things were happening and pushing government stakeholders to get things done."

The practical implications of the political and royal support for the project were visibly manifested in the empowerment of the Team Leader, who acquired the power to make all critical decisions and navigate all government agencies to gain the necessary approvals. He stated that, "PPP projects need one individual who has the power and guts to implement all projects and make good decisions." With the Royal Order as a backstop, this was not too difficult to achieve. Although most saudi bureaucratic organizations are characterized by rigid hierarchical processes, GACA's chairman transferred a considerable capacity for making autonomous decisions to the PPP Team Leader and delegated many responsibilities to other senior members of the team to accelerate the decision-making process. These were innovations that severely challenged the business as usual of Saudi bureaucracy; without the 
social integrational elements of the project, the project would have likely failed.

\section{Work to disempower agency of resisting actors}

The political empowerment of the PPP project, by enacting systemic power over the institutionalized form of project delivery, destabilized the status quo. It entailed a new project financing model, rigid project governance mechanisms that had hitherto not existed in the construction domain, a new procurement method as well as a drastic shift in status for government employees within the airport who were suddenly obliged be subordinate to a private employer. The effects of enforcing the PPP method on individual and organizational actors are summarized in Table 2 below, which also illustrates the repair work necessary to alleviate those effects.

Opening the local market to foreign competitors as a disadvantage to local companies. The monopoly of a few powerful Saudi business families over the construction industry had in the past institutionalized aa regime in which they were able to exercise dominance in the delivery of large infrastructure government contracts (House, 2013; Ali, 2010). The introduction of a PPP model with private financing and strict due diligence mechanisms exercised by international banks and investors meant that the processes of project procurement would be drastically different. Given the sophisticated technical requirements of airport expansion and the high complexity of its operation and management of the tremendous number of pilgrims visiting Medina, it was evident that local private actors would be immediately disqualified and lose ground to more advanced international companies. They could not rely on the traditional channels of patronage to deliver the contracts, and an interviewee representing an international organization stated:

"In Medina, several local merchant families tried to push us so hard to give them project contract, and many of them were very powerful, but we managed it, and everyone understood that the qualified consortium would win. This is one of the biggest challenges we faced with PPPs. I see it the biggest hindrance."

Forcing the bureaucracy to administer the PPP leading to frustration and lack of capacity. The royal and administrative decrees to expand the airport and operate it through the private sector challenged standardized bureaucratic and administrative procedures. The most difficult challenge was shifting the bureaucratic mentality of delivering government projects through 
the traditional EPC method. The bureaucrats in control could dictate contracts and set specific deliverables. The consortia led by a private operator, flipped this assumption and set new rules of the game. There were no policies, procedures, templates, laws, regulations, or guidelines that government departments and line ministries could rely on to respond to the requirements of GACA and its teams' formalization of the documentation for the BTO agreement, while the political backing that the project enjoyed meant that these government entities could not reject the project or challenge its implementation. GACA had social and system integration wrapped up and under these conditions seemed able to configure all the circuits of power accordingly. It had, in terms of direction from above and managing upwards, achieved both system and social integration. Managing down was another matter.

\section{---- Table 2 about here----}

operating the project via a private entity causing fear, confusion, and resistance among employees. While it can be said that the institutional context of Saudi Arabia was the major problematic issue prior to signing the PPP contract, one senior government official explained that, after signing, it was the airport's management and staff who became the "biggest challenge the project faced, since they refused to transfer to a private operator." The transfer of the airport into the hands of a private operator had a dramatic impact on the management and employees of the airport. It meant a shift from being a public employer to one that was private. There was no evidence in the data to suggest that the employees and staff of the airport were a part of the change process from the outset, or that they had been consulted or properly prepared for it prior to the contract signing. The change caused not only temporary loss of status but also a permanent shift in their organizational identity and radical alteration of how they performed their daily tasks. Different and increased expectations of performance prevailed, and new uncertainties arose.

Employees felt that terminating their contracts and employment as public sector workers threatened their job security. Although public sector jobs paid much less, what was crucial for the airport's management and the staff was lifelong job security, longer holidays and familiarity with the relaxed government system. Their posts were, in effect, sinecures. In contrast, private-sector jobs were more demanding and performance-based, and renewal of contracts every three years was predicated on meeting specific KPIs and competitive criteria. Furthermore, drastic changes would also be implemented in the form of rigid requirements 
concerning attendance and promotion, with new technical equipment being introduced to operate the airport. All of these changes required considerable skills that many employees did not have, which some of them were not prepared to invest time and effort to learn. The need for the changes was also unclear to many airport employees who demanded that they remain under the umbrella of GACA as government employees while working for the operator. Almost all interviewees stressed that the refusal of the airport's employees to transfer to the private operator was the "biggest challenge" the project faced, one that took considerable time. The PPP Team Leader stated that:

"...main challenges we faced after signing the agreement were with employees because they were used to working with the public sector and they felt secure, and protected, and no one could fire them regardless of performance. But with the private sector they must be on time, and attendance and performance are evaluated all the time."

Employees complained that the implementation of the project took two years, while they were given only one week to decide which option they would choose (Al-Sharq, 2012b). They did not find the private sector offers attractive and refused those options, and expressed their resistance by writing letters expressing their contempt of joining the private operator to the King and human rights organizations and asking to keep their government contracts and benefits (Al-Sharq, 2012a). Employees also lodged a legal case against GACA at the administrative tribunal complaining about the illegality of forcing them to transfer and terminate their government contracts, but after five months, the employees lost their legal case (World of Money, 2012). They were consequently forced to choose among four options: 1) transfer to the operator under a new contract and be subject to private employment law; 2) be seconded to the airport for three years and then begin a new contract with the private operator; 3) look for a new job and transfer to any other airport in the Kingdom or 4), seek a new job with other government entities (Al-Sharq, 2012b). In absolutism, bureaucracy in Saudi Arabia is really perceived as patrimonial and employees' resistance, based on dispositions enculturated in the past pattern of indulgence that their sinecures had enjoyed, stalled the project and caused delays in the commercial operation of the airport. Nonetheless, employees were given four options that did not alleviate their fears of abrupt organizational change taking place at the airport.

\section{Repair work}


Disempowerment of public, private, and administrative actors required repair work to alleviate the negative effects caused by the abrupt pressures of system integration work on them. In spite of their resistance, employees' choices were restricted, and they were obliged to transfer to the private operator. There were pecuniary advantages, but the expectations of the implicit effort bargain were radically different.

Establishing good project governance and transparency mechanisms. The involvement of IFC in the project offered a robust project-governance mechanism. Existing anti-corruption arrangements and institutions had yet to win the trust of international investors well-versed in saudi corrupt and patrimonial practices (Ali, 2010). According to one senior representative of an international organization, during the tendering process for the airport project, some local construction giants attempted "to push the envelope very hard because they wanted the project badly," but were unsuccessful. The envelopes being pushed were unlikely to have been purely metaphorical.

With the backing of its social and system integration GACA was enabled to empower IFC, build strong project governance principles, increase the project tendering process's transparency and ensure that only a bidder that met all of the technical requirements and that had an attractive financial proposal would win the project contract. GACA outflanked local construction companies accustomed to exercising power to win projects one way or another, not always in transparent, ethical or scrupulous ways (House, 2013). The capacity to select a competent entity led to the choice of a private sector actor with extensive experience in constructing and operating airports.

Maintaining dialogue, sensegiving, and developing a partnership. GACA's team worked to engage in effective communication and dialogue with private partners. At this stage, the number of actors increased significantly. The project's field included GACA's team, the IFC's team, representatives of local and international banks, insurance companies, prequalified bidders, plus a complex arrangement of technical, legal and financial consultants. A sense of partnership and dialogue was critical, as was transparency in presenting all data related to the financial, legal and technical components of the project. Hiring experienced international consultants overcame the lack of local expertise in administering PPP contracts. Something identified as a critical success factor by several interviewees. The role of the consultants was essential not only due to the absence of customary legal, financial and technical mechanisms for such projects but also 
because they translated international best practices in designing $\mathrm{PPP}$ contracts for airports into Saudi Arabia. International investors were comfortable with international arrangements that were customized to fit the local culture and environment.

The legal consultants drafted standard contracts that were used in airports internationally and put into place a general framework to guide the BTO agreement, which served as the primary governing mechanism for the partnership. The contract would be the critical foundation of the partnership for 25 years, so it needed to be comprehensive and to satisfy both parties. A clear BTO contract was designed by the consultants in conformance with international standards and included clauses for issues such as international arbitration, which Saudi Arabia did not have the institutional capacity to arrange. The private sector was permitted the flexibility to design the operational and managerial procedures and models with few restrictions to allow it to create innovative and efficient solutions. The involvement of a private partner that financed, constructed, managed, and operated a public entity as politically sensitive as an airport was not only unprecedented and contradictory to all existing laws and regulations but also risked loss of government control over that particular asset. Furthermore, the entire institutional ecosystem in Saudi Arabia was unaccustomed to having the private sector dictate rules of engagement. Typically, the public sector, the traditional purchaser of services, would set the rules and expectations to be met by the service providers.

The former chairman of GACA stated that their key strategy was "to keep all of the ministries and government entities that were influential in the project informed of everything that [they] did." GACA did not base its strength on just on the official decrees that empowered it but also founded it on proper communications with all government stakeholders, explain to them the importance and utility of the project. More importantly, they showed that the exceptions granted to deliver the project would not affect the overall institutional arrangements of the country. Such sensegiving mechanism demonstrated the importance and uniqueness of the project to all public entities. The method proved fruitful. The decentralization of decision-making allowed the "project champion" to directly meet with government officials, sign necessary documents and enforce decisions. The project champion also filled in cracks in the bureaucratic system and ensured that things were moving smoothly for the project by making direct visits to government entities. He did not rely merely on correspondence, which would have slowed down the speed of the project but worked socially. The private partners played an 
instrumental role in this process as well. Although GACA's team was on the front lines during negotiations with government entities, the private consortium was also equally flexible and supportive when they faced deadlocks.

Readjusting organizational identity, persuasion, capacity building, and laying off redundant employees. The airport employees and staff did not have any other choice but to transfer to the private operator despite their resistance and dissatisfaction. They were subject to an unassailable episodic power. Despite the coercion mobilizing the employees' transfer, the actual process of implementing the change was more benign. The former head of GACA'S PPP unit said that they "did not engage in conflict with the employees" but instead motivated them to accept the change in the operation of the airport by a private actor by emphasizing its benefits, particularly stressing that it would enable more Muslims to perform pilgrimages. A government employee stated that "we kept telling employees that their work and support for the project would be rewarded in the hereafter as they would be supporting Muslims to perform their religious obligation, and a lot of them resonated with this idea." To corroborate this point, during a regular visit to the Medina Airport during the pilgrimage season, the Prince of Medina was cited as saying to immigration officers: "you are gaining considerable reward from God by serving pilgrims in a good manner" (News24, 2018). The religious symbolism was not only persuasive and accorded with the vocabularies of motive of pious Muslims but also offered the comfort that they were working not just for the airport but for the praise of Allah.

A special committee was formed to listen and respond to employees' concerns, compensating those that wished to leave the organization and preparing those that had decided to stay for their new roles. The key factor ending the employees' resistance and facilitating their transfer to the private operator was that they would only transfer on a secondment basis for three years as government employees. During this period, they would either adjust to the new work environment or have ample time to find new jobs at other government entities. Workers would remain government employees with all of the accompanying benefits and job security, but at the end of the three years period they would need to decide whether to sign a new contract as private employees or resign. In addition to boosting morale, monetary incentives were also offered. Employee salaries were increased by 20\%, housing allowances, health insurance and other benefits that had not existed within the old system were offered. Education and training of employees in the new organizational structures and practices were essential for their integration into the changing 
organizational identity and culture. One private-sector interviewee noted that "a total of 630 training days were offered both on-site in Medina and in Istanbul" where TAV, the consortia, had its headquarters. These training programs, aimed at both the technical and psychological readiness of employees, were aimed effectively to enhance preparation for the new roles and responsibilities.

After initiating a program for building employees' skills and motivation to accept change, the institutional work of GACA and its partners shifted toward the progressive introduction of new structures and systems that would prepare the airport for a new managerial style. Key structural changes included the introduction of both mechanical tools and human resource management techniques. The establishment of new operational and organizational structures meant the birth of a new airport with new international standards and notably higher performance. The change was drastic, affecting everything about the way the airport had been run under the old administration, ranging from the quality of ground and passenger services to the equipment adopted to maintain and service aircraft. The introduction of these new techniques was gradual, with on-site training being offered to ensure that the same employees could operate new systems.

New human resource practices were introduced, as well as strict KPIs that employees needed to achieve. To guarantee the efficiency of the workforce, private-sector's business acumen and dynamism were injected into the airport's management style resulting in a novel break from the past. New practices were introduced regarding attendance, promotion and contract renewal, which were now determined by performance and output. These mechanisms enforced the private sector practices of conforming to rigid achievement criteria and reaching specific outcomes and targets.

Nonetheless, not all employees were prepared to embrace change nor invest the effort to support the Muslim community's pursuit of pilgrimage. Only 53\% of employees transferred to the private company operating the airport when the 3 years secondment ended in 2015 (Sabaq, 2015). The remaining employees either transferred to other airports or took another government job or remained under the umbrella of GACA and worked for another government entity (Sabaq, 2015). Furthermore, the private operator of the airport laid off 200 employees in May 2017, and provided a few of them the chance of renewing their contracts provided that they agreed on lower salaries and benefits (Al-Madinah, 2017). The government did not intervene in the dismissal of the employees as 
the BTO agreement specified that the private sector could recruit and maintain only well-performing individuals, and only on this basis could the private operator maintain a positive return on investment in the long run by hiring more efficient employees.

\section{Discussion and conclusions}

The two central research questions guiding this study aimed to examine the types of institutional work that individual actors performed to gain the power to initiate new forms of project delivery and how the resultant modes of power were employed to relax the controlling mechanisms of past institutional structures. By connecting the PPP literature with recent developments in neoinstitutional theory, this research makes the following three contributions.

The first contribution is that it broadens the scope of the means through which individual actors aim to "achieve particular institutional objectives" (Hampel et al., 2017, p. 570). It is evident from the list of 15 types of institutional work developed by Phillips and Lawrence (2012) that scant attention has been paid to how religious beliefs shape or fuel the institutional work carried out to change organizations or institutions (See also Tracey et al., 2014). Such lack of attention to the role of religion in shaping institutions is surprising, as religion plays a key role in institutional ordering at the societal level in the majority of societies, particularly those that adhere to Islamic doctrines. In an absolutist and Wahabi state such as Saudi Arabia, there is no greater political support than the duty to Allah and to the Sovereign. The paper extends the institutional work debate by proposing religious symbolic work, which denotes how actors purposefully employ shared religious beliefs to influence the decision-making of powerful actors who can enable and empower the implementation of new forms of project organizing.

As the case analysis reveals, the fundamental mechanism that the actors proposing the PPP model used to instigate interest in the project was by emphasizing its religiosity. The work to convince high-ranking officials to support the project was welcomed because there was a socially and culturally embedded common understanding among all actors that they were supporting a religious cause, rather than a standard construction project. In order to gain access to political power and overcome the structural barriers blocking the PPP model, actors touting the PPP model devised strategies by which they associated their work with several religious symbols. Unlike several infrastructure projects in the country which were initially proposed as PPPs but never received 
the necessary high-level political backing, emphasizing the project's religious significance made it an exception and convinced all political actors involved in the decision-making that the PPP was the right method. Bathed in the ethos of this religious motive for social integration, the project was approved in the ministerial council meetings and then received a Royal Order which portrayed the project as a national high-priority.

The interplay and tight connection of social and system integration through the symbolic capital of religious and royal/political interconnectedness are not documented in organizational studies in the western context. The demarcation between church and state and the boundaries between politics and administration are, in most cases, well-established in these countries. The Muslim world is different, a difference that has a significant effect on managing and organization, as this study demonstrates, even when the forms of organization that are being implemented have developed in a western context, as did PPP. In the absence of clearly defined institutional fields of church, state, business and civil society, it is necessary to broaden the conceptualization of the power of systemic integration. It is important to shift theorization of power from organizations into broader environments in which heads of state and political actors play significant roles, and all are underpinned as manifestations of power by religious beliefs that make social integration cohere quite overtly, as the case in Saudi Arabia.

In a similar vein, this paper offers new insights into project management research. The findings of this paper advance such research by revealing that religious symbolic work can be a powerful mechanism to drive megaprojects. The appealing factors in the project were not just its economic value and potential to create new jobs and expand the tourism industry of the city but also its role as an enabler that would allow millions of extra pilgrims to fulfill their religious obligations each year. The political elite's intimate involvement in the project reflects the intricate links between religious beliefs and how they affect the cognitive realities of political actors, encouraging them to support project forms that did not fit existing institutional structures. The political actors supporting this project, such as the King, fulfilled not only their obligation to facilitate the journey of Muslims to the holy mosques, but also sponsored spiritual gratification and enjoyment.

Second, by analyzing how circuits of power facilitated the PPP project implementation process, the research expands the discussion regarding the bases and the inter-dependence among 
several forms of power in organizational theory and project management. The discussion of power in organizational studies is predominantly concerned with how actors use power to shape the formulation of strategy. It is limited to how management exercises the power to implement new strategic objectives (McCabe, 2009), how power circulates through discourse to shape the creation of new strategies (Hardy and Thomas, 2014), and the roles of episodic and systemic powers in radical organizational change (Lawrence et al., 2012). The power dynamics presented in this literature usually involve actors' private organizations embedded within market logics, revealing tactics used by actors in the upper levels of hierarchies to exercise episodic power and change certain aspects of the organizations.

However, despite the crucial role of power relations in megaprojects, Clegg and Kreiner (2013) have noted that power remains a rare subject in project management research. When power is discussed in this field, it is often depicted as a "dirty word" (Clegg et al., 2017, p. 7), or a negative force that obstructs projects. This paper is situated among the few studies that discuss how power dynamics shape projects and demonstrate innovative ways in which power can be a positive force that drives the project implementation process forward. The findings are similar to those of Walker and Newcome (2000), who found that several individual actors built on their organizational power to successfully drive the development of the Hong Kong University of Science and Technology. They emphasized the power of external and internal coalitions such as the Jockey Club and the Planning Committee that collectively exercised organizational power to in order to push the project forward while the role of the government was passive. Similarly, Liu et al., (2003) have argued that power in projects is represented in both interpersonal and organizational structural forms, and this is in line with our findings as well.

We developed a process model that depicts how the episodic and systemic forms of power operated in a manner illustrating the effects of each mode of power. As demonstrated in Figure 2, the religiosity of Medina and airport project was emphasized to build and develop actors' sources of power. Because these actors were attempting to convince elite political actors to legitimize the PPP model, their exercise of episodic power sought successfully to activate political interest and support for the PPP, manifested in two forms. The first was the empowerment of the PPP project through several ministerial decrees and a Royal Order that forced the implementation of the project, regardless of its severe repercussions on several organizational and individual actors, including private actors, the bureaucracy and the airport 
employees. It was not a process that had institutional legitimacy in the Saudi context, but religiosity seemed to overpower any other social considerations.

---- Figure 2 about here----

By extending the empirical context to an absolutist state in which political power is top-down, this study addressed the call for research to demonstrate how power shapes organizational change (Lawrence et al., 2001; Lawrence, 2008). The use of social integration was critical in this case, since none of the actors affected would have voluntarily accepted the private sector logic, nor supported the institutional work required to implement the project in a non-traditional manner. The force of the religious ethic behind social integration disempowered resistant agency associated with the project, restricted their options, obliging acceptance of a new organizational reality that people were unaccustomed to. The project had unlimited authority and capacities bestowed on it by the congruence of social and system integration, despite being radical and creative destruction of conventional ways of doing things in the Saudi bureaucracy, the destruction that led to the necessity for repair work. Systemic power is typically seen as embedded within social, cultural, bureaucratic and technological forms (Clegg, 1989; Lawrence et al., 2001). In this research, systemic power is premised not only on the system integration, but also the social integration encompassing the symbolic interconnectedness of religious with royal, political and administrative bases. In this empirical context, the motivation to achieve religious gratification by supporting Muslims in their pilgrimage is due to the impact of religion as a power for social integration that is invisible in its causal workings but deeply affects decision-making processes.

Third and finally, by extending Lawrence and Suddaby's (2006) typology of institutional work to a PPP project located in an adverse institutional environment, this article made an analytical shift from the macro and meso levels to the micro-level. Doing so allowed the research to capture the invisible efforts of individual actors which are currently overlooked in the PPP and project management disciplines, as well as how a stable equilibrium between agency and structure was achieved. While previous research has adopted a top-down approach and shown that PPP-enabling organizational fields are critical drivers of PPP implementation (Jooste and Scott, 2012b; Verhoest et al., 2015; van den Hurk and Verhoest, 2015; Mahalingam and Delhi, 2012; Matos-Castaño et al., 2014), this research adopted a bottom-up approach that uncovered institutional workers' strategic use of power to create a 
triumphant story of drastic organizational change. Undermining the forces of structure required the "knowledgeable, creative and practical work" of actors who disrupted the operational model of public organization by acquiring and utilizing several forms of power (Lawrence and Suddaby, 2006, p. 219). In the present case study, we showed that the actors leading this change effort understood the influence of political and religious powers and how to mobilize the social integrational power of religious symbolism to force a change that was radical for its context. 


\section{References}

Agyenim-Boateng, C, Stafford, A \& Stapleton, P. (2017), The role of structure in manipulating PPP accountability, Accounting, Auditing and Accountability Journal, $30(1), 119-144$.

Al-Riyadh. (2006). The Custodian of the two holy mosques announced transforming Medina Airport into an international airport.AlRiyadh.

Al-Riyadh. (2009). Delayed infrastructure projects are hindering development. Al-Riyadh.

Al-Riyadh. (2013). Anti-corruption authority: delayed governmentfunded infrastructure projects cost more than 40 billion Riyals a year. Al-Riyadh.

Al-Sharq. (2012a, 2012/04/02). Employees of Medina Airport confirm they complained to a human rights' organization...but the responsible for the organization denies that. Al-Sharq.

Bailey, J., \& Raelin, J. (2015). Organizations don't resist change, people do: Modeling individual reactions to organizational change through loss and terror management. Organization management journal, 12,125-138.

Ballantyne, B. (2011). Medina sets model for airport schemes. MEED: Middle East Economic Digest, 55(51), 44-45.

Biygautane, M. (2017). Infrastructure Public-Private Partnerships in Kuwait, Saudi Arabia, and Qatar: Meanings, Rationales, Projects, and the Path Forward. Public Works Management \& Policy, $22(2), 85-$ 118 .

Clegg, S. (1989). Frameworks of power. London: Penguin Books.

Clegg, S. (2010). The State, Power, and Agency: Missing in Action in Institutional Theory? Journal of management inquiry,19(1), 4-13.

Clegg, S., \& Courpasson, D. (2004). Political Hybrids: Tocquevillean Views on Project Organizations. Journal of management studies, $41(4), 525-547$.

Clegg, S., \& Kreiner, K. (2013). Power and Politics in Construction Projects. In R. Drouin, R. Müller, \& S. Sankaran (Eds.), Novel Approaches to Organizational Project Management Research:

Translational and Transformational (pp. 268 - 293). Copenhagen: Copenhagen Business School Press.

Connolly, C., Reeves, E., \& Wall, A. (2009). Isomorphism: An Explanation for the Popularity of Public-Private Partnerships? Irish Accounting Review,16(1),1-19.

DiMaggio, P., \& Powell, W. (1983). The Iron Cage Revisited: Institutional Isomorphism and Collective Rationality in Organizational Fields. American Sociological Review,48(2),147160 .

Eisenhardt, K., \& Graebner, M. (2007). Theory Building From Cases: Opportunities And Challenges. Academy of management Journal, $50(1), 25-32$.

Fenton, S. (2011). Turkish-led team wins Medina PPP. MEED: Middle East Economic Digest, 55(32), 1-3. 
Gawer, A., \& Phillips, N. (2013). Institutional work as logics shift: The case of Intel's transformation to platform leader.

Organization studies,34(8), 1035-1071.

Gioia, D., Corley, K., \& Hamilton, A. (2013). Seeking Qualitative Rigor in Inductive Research: Notes on the Gioia Methodology. Organizational research methods,16(1), 15-31.

Göhler, G. (2009). 'Power to' and 'Power over'. In S. Clegg \& M. Haugaard (Eds.), The SAGE Handbook of Power. London:Sage.

Hampel, C., Lawrence, T., \& Tracey, P. (2017). Institutional Work: Taking Stock and Making it Matter. In R. Greenwood, C. Oliver, T. Lawrence, \& R. Meyer (Eds.), SAGE Handbook of Organizational Institutionalism (2 ed., pp. 558-590). London: UK:Sage.

House, K. (2013). On Saudi Arabia: Its people, past, religion, fault lines-and future. New York: Vintage Books.

IFC. (2013). Public-private partnership impact stories Saudi Arabia: Hajj airport terminal. Retrieved from http://ww.ifc.org/wps/wcm/

Jooste, S., \& Scott, R. (2012b). The public private partnerships enabling field: Evidence from three cases. Administration and society, $44(2), 149-182$.

Kamrava, M. (2018). Inside the Arab State. London: United Kingdom: C Hurst \& Co Publishers Ltd.

Khadaroo, I. (2008). The actual evaluation of school PFI bids for value for money in the UK public sector, Critical Perspectives on Accounting, (19) 8,1321-1345.

Koppenjan, F. M. (2008). Public-private partnership and mega-projects. In H. Priemus, B. Flyvbjerg, \& B. van Wee (Eds.), Development and Management of Large Infrastructure projects (pp. 189-212). Cheltenham: UK: Edward Elgar.

Lawrence, T. B, \& Suddaby, R. (2006). Institutions and institutional work. In S. Clegg, C. Hardy, T. Lawrence, \& W. Nord (Eds.), Handbook of organization studies (2nd edition ed., pp. 214-254). London: Sage.

Lawrence, T. B, Suddaby, R., \& Leca, B. (2009). Introduction: theorizing and studying institutional work. In T. Lawrence, R. Suddaby, \& B. Leca (Eds.), Institutional work: Actors and agency in institutional studies of organizations. Cambridge: Cambridge university press.

Lawrence, T. B. (2008). Power, Institutions and Organizations. In G. Royston, O. Christine, S. Roy, \& S. Kerstin (Eds.), Handbook of Organizational Institutionalism (pp.170-197).London: Sage.

Lawrence, T. B., Leca, B., \& Zilber, T. (2013). Institutional Work: Current Research, New Directions and Overlooked Issues. Organization studies, 34(8), 1023-1033.

Lawrence, T. B., Malhotra, N., \& Morris, T. (2011). Episodic and Systemic Power in the Transformation of Professional Service Firms. Journal of management studies,49(1), 102-143.

Lawrence, T. B., Mauws, M., Dyck, B., \& Kleysen, R. (2005). The Politics of Organizational Learning: Integrating Power into the 4 I Framework. Academy of Management Review,30(1),180-191.

Lawrence, T. B., \& Robinson, S. (2007). Ain't Misbehavin: Workplace Deviance as Organizational Resistance. Journal of management, 33(3), 378-394. 
Lincoln, S., \& Guba, E. (1985). Naturalistic inquiry. Beverly Hills: Sage.

Lofland, J., \& Lofland, L. H. (1995). Analyzing social settings: A guide to qualitative observation and analysis. CA: Belmont: Wadsworth Publishing Company.

Lopez-Rego, M., Irigaray, H. A. R., \& Chaves, R. L. P. (2017) . Symbolic Megaprojects Historical Evidence of a Forgotten Dimension. Project Management Journal,48(6), 17-28.

Mahalingam, A., \& Delhi, V. (2012). A contested organizational field perspective of the diffusion of public-private partnership regimes: evidence from India. Engineering Project Organization Journal,2(3), 171-186.

Matos-Castaño, J., Mahalingam, A., \& Geert Dewulf, G. (2014). Unpacking the Path-Dependent Process of Institutional Change for PPPs. Australian Journal of Public Administration,73(1), 47-66.

Mazouz, B., Facal, J., \& Viola, J. M. (2008). Public-private partnership: Elements for a project-based management typology. Project Management Journal,39(2),98-110.

McQuaid, R., \& Scherrer, W. (2010). Changing reasons for publicprivate partnerships (PPPs). Public Money and Management, $30(1), 27-34$.

Ouadou, M. (2000, 17/12/2000). Prince of Medina confirms the expansion of Medina Airport with the Council of Ministers and train project with privatization committee. Al-Hayatt.

Phillips, N., \& Lawrence, T. B. (2012). The turn to work in organization and management theory: Some implications for strategic organization. Strategic Organization,10(3),223-230.

Rye, D. (2015). The concept of power in the analysis of organisations with social and political goals. Journal of Political Power, 8 (3), 301-320.

Sabq. (2015). The King will inaugurate the Medina Airport tomorrow. Sabq.

Scott, R. (2008). Approaching Adulthood: The Maturing of Institutional Theory. Theory and Society, 37(5), 427-442.

Scott, R. (2014). Institutions and organizations: Ideas, interests, and identities (4th ed.). CA:Los Angeles:Sage.

Shaw-Smith, P. (2011, 17 May 2011). Saudi Landbridge rail project loses momentum. Financial Times. Retrieved from https://www.ft.com/content/e4f4a056-7fd7-11e0-b018-00144feabdc0

Sheppard, G., \& Beck, M. (2016). The evolution of public-private partnership in Ireland: a sustainable pathway? International Review of Administrative Sciences,1-17.

Söderlund, J., Sankaran, S., \& Biesenthal, C. (2017). The Past and Present of Megaprojects. Project Management Journal, 48(6), 5-16.

Strauss, A., \& Corbin, J. (1998). Basics of Qualitative Research: Techniques and Procedures for Developing Grounded Theory. Thousand Oaks: CA: Sage Publications, Inc.

van den Hurk, M., \& Verhoest, K. (2015). The governance of publicprivate partnerships in sports infrastructure: Interfering complexities in Belgium. International Journal of Project Management, 33(1), 201-211. 
van der Westhuizen, J. (2017). Megaprojects as Political Symbols: South Africa's Gautrain In B. Flyvbjerg (Ed.), The Oxford Handbook of Megaproject Management. Oxford:Oxford University Press.

Van Maanen, J. (1979). The Fact of Fiction in Organizational Ethnography. Administrative science quarterly,24(4), 539-550.

Verhoest, K., Petersen, O. H., Scherrer, W., \& Soecipto, R. M. (2015). How Do Governments Support the Development of Public Private Partnerships? Measuring and Comparing PPP Governmental Support in 20 European Countries. Transport Reviews,35(2), 118-139.

Walker, A., \& Newcombe, R. (2000). The positive use of power on a major construction project. Construction Management and EConomics,18(1), 37-44.

Yin, R. (2014). Case Study Research Design and Methods (5 ed.). CA:Los Angeles: Thousand Oaks.

Zilber, T. (2007). Stories and the Discursive Dynamics of Institutional Entrepreneurship: The Case of Israeli High-tech after the Bubble. Organization Studies,28(7),1035-1054 


\section{Tables and Figures}

\section{Figure 1: Data structure}

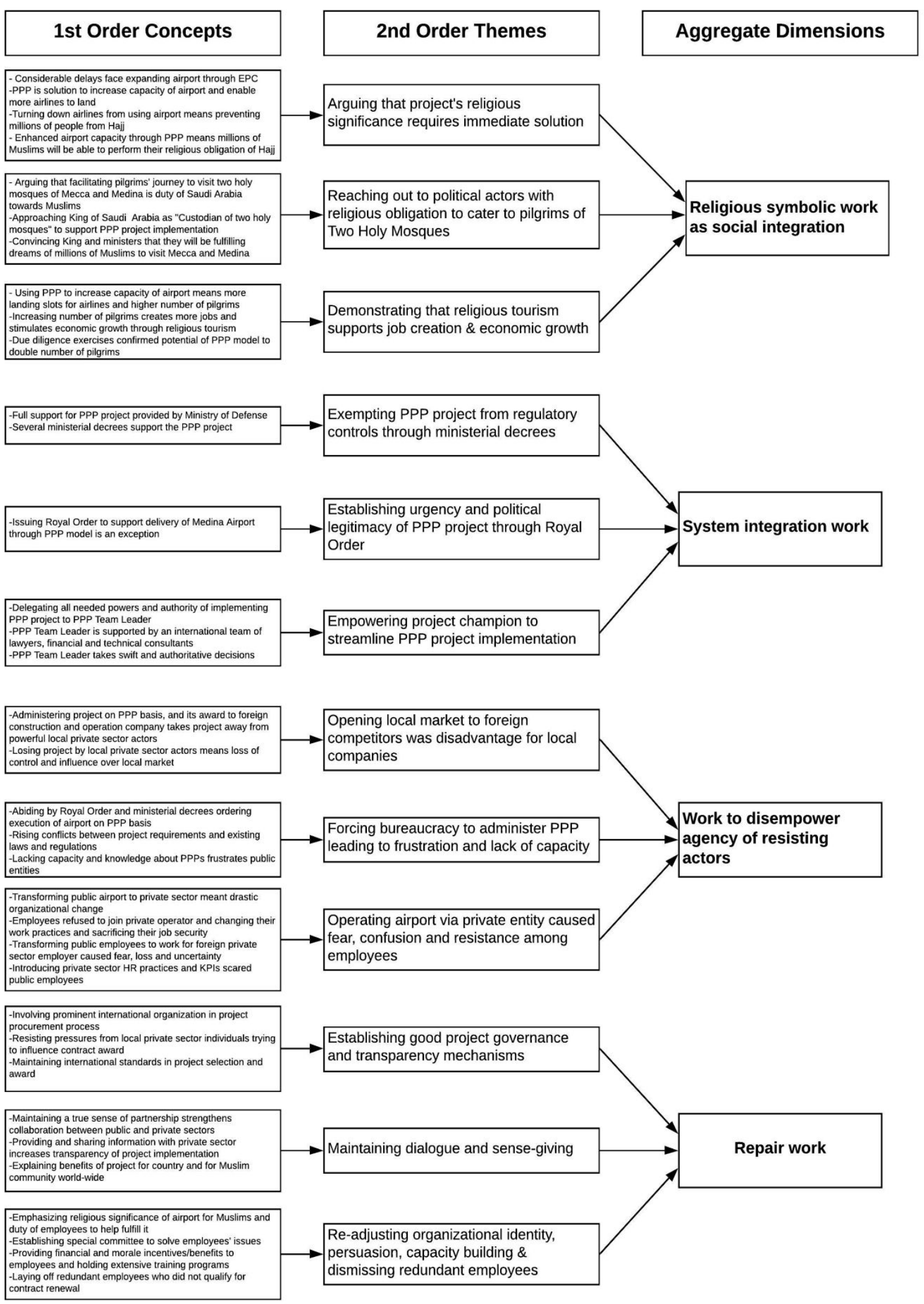


Table 1: Forms of power and their impact on implementation of PPP project.

\begin{tabular}{|c|c|c|}
\hline Forms of power & $\begin{array}{l}\text { Modes in which } \\
\text { power operated }\end{array}$ & $\begin{array}{l}\text { Effects of power on routinized ways of } \\
\text { project delivery }\end{array}$ \\
\hline King's order & $\begin{array}{l}\text { System and } \\
\text { social } \\
\text { integration }\end{array}$ & $\begin{array}{l}\text {-Provided political legitimacy and urgency of } \\
\text { delivering project through PPP. } \\
\text {-Enforced responsiveness and adherence of all } \\
\text { concerned actors and organizations in project } \\
\text { implementation. }\end{array}$ \\
\hline $\begin{array}{l}\text { Decree from Supreme } \\
\text { Economic Council }\end{array}$ & $\begin{array}{l}\text { System } \\
\text { integration }\end{array}$ & $\begin{array}{l}\text { Exempted PPP project from regulatory controls } \\
\text { of GPTL and allowed use of BTO agreement } \\
\text { instead. }\end{array}$ \\
\hline $\begin{array}{l}\text { Decree from Council of } \\
\text { Ministers }\end{array}$ & $\begin{array}{l}\text { System } \\
\text { integration }\end{array}$ & $\begin{array}{l}\text { Removed bureaucratic and administrative } \\
\text { barriers blocking PPP project by issuing } \\
\text { decree that required all concerned entities } \\
\text { to issue exceptions to normalized ways of } \\
\text { working. }\end{array}$ \\
\hline $\begin{array}{l}\text { Financial guarantees } \\
\text { from Ministry of } \\
\text { Finance }\end{array}$ & $\begin{array}{l}\text { System } \\
\text { integration }\end{array}$ & $\begin{array}{l}\text { Made project bankable and increased trust of } \\
\text { lenders and investors in project. }\end{array}$ \\
\hline $\begin{array}{l}\text { Support from Ministry } \\
\text { of Defense }\end{array}$ & $\begin{array}{l}\text { System } \\
\text { integration } \\
\text { /episodic }\end{array}$ & $\begin{array}{l}\text { Represented royal influence and power of } \\
\text { Minister of Defense and provided letters of } \\
\text { support whenever needed. }\end{array}$ \\
\hline $\begin{array}{l}\text { Administrative Ruler } \\
\text { of Medina }\end{array}$ & $\begin{array}{l}\text { System } \\
\text { integration/ } \\
\text { episodic }\end{array}$ & $\begin{array}{l}\text { Issued orders to facilitate administrative } \\
\text { work required for project implementation. }\end{array}$ \\
\hline $\begin{array}{l}\text { Executive powers of } \\
\text { Steering Committee }\end{array}$ & $\begin{array}{l}\text { System } \\
\text { integration/ } \\
\text { episodic }\end{array}$ & $\begin{array}{l}\text { - Oversaw day-to-day requirements of project } \\
\text { by holding weekly meetings and fully } \\
\text { supporting work of project champion. } \\
\text { - Removed regulatory and bureaucratic } \\
\text { obstacles facing project by issuing } \\
\text { exceptions to them. }\end{array}$ \\
\hline GACA's president & Episodic & $\begin{array}{l}\text {-Streamlined internal decision-making } \\
\text { processes. } \\
\text {-Endorsed private sector's requests to } \\
\text { government entities. }\end{array}$ \\
\hline $\begin{array}{l}\text { Professional power of } \\
\text { project champion }\end{array}$ & Episodic & $\begin{array}{l}\text { - Decentralized bureaucratic pressures, with } \\
\text { power to act autonomously meaning effective } \\
\text { and instant decision-making processes. } \\
\text {-Led entire project implementation process. }\end{array}$ \\
\hline
\end{tabular}


Table 2: Effects of system integration and repair work on individual and organizational actors

\begin{tabular}{|c|c|c|c|}
\hline & $\begin{array}{l}\text { Impact of system integration on } \\
\text { actors and organizations }\end{array}$ & $\begin{array}{l}\text { New PPP project requirements which } \\
\text { changed routine ways of operating }\end{array}$ & $\begin{array}{l}\text { Repair work to alleviate impact of system } \\
\text { integration and implement project }\end{array}$ \\
\hline $\begin{array}{l}\text { Local private } \\
\text { sector actors }\end{array}$ & $\begin{array}{l}\text {-Local private construction companies } \\
\text { lost project to international firm. } \\
\text {-Local private actors' capacity to } \\
\text { influence project award decision was } \\
\text { eliminated. } \\
\text {-Operation of project was handed over } \\
\text { to international firm. } \\
\text {-It was stipulated that project would } \\
\text { be awarded only to actors with } \\
\text { technical capacity to administer } \\
\text { projects' requirements. }\end{array}$ & $\begin{array}{l}\text { - Sophisticated expertise in } \\
\text { constructing and operating } \\
\text { complex airport projects. } \\
\text { - High levels of efficiency in } \\
\text { operating airport over 25-year } \\
\text { period. } \\
\text { - High levels of transparency in } \\
\text { bidding for project. }\end{array}$ & $\begin{array}{l}\text { Establishing good project governance } \\
\text { mechanisms: } \\
\text { - Involving IFC during all stages of tendering, } \\
\text { bidding, and awarding project, which provided } \\
\text { strong governance and transparency-related } \\
\text { mechanisms. } \\
\text { - Selecting only private actors with proven } \\
\text { capacity to expand and operate airport } \\
\text { efficiently. }\end{array}$ \\
\hline $\begin{array}{l}\text { Bureaucratic } \\
\text { and } \\
\text { administrative } \\
\text { actors }\end{array}$ & $\begin{array}{l}\text {-All government departments were } \\
\text { unfamiliar with concept of PPP. } \\
\text {-New form of project organizing } \\
\text { required different contractual and } \\
\text { administrative measures that Saudi } \\
\text { bureaucracy did not have capacity to } \\
\text { administer. } \\
\text {-Government departments could not } \\
\text { make decisions that were not aligned } \\
\text { with existing legal and regulatory } \\
\text { frameworks. } \\
\text {-Handing airport to private operator } \\
\text { that would decide "rules of the game" } \\
\text { led to frustration among government } \\
\text { entities. }\end{array}$ & $\begin{array}{l}\text { - Familiarity with PPP concept and } \\
\text { implementation process. } \\
\text {-Capacity to administer legal and } \\
\text { regulatory requirements for } \\
\text { drafting PPP contract. } \\
\text {-Handover of project to private } \\
\text { sector. } \\
\text {-Understanding of requirements of } \\
\text { successful partnership with } \\
\text { private sector. }\end{array}$ & $\begin{array}{l}\text { Sensegiving: } \\
\text {-Explaining importance of project for Muslims } \\
\text { all over the world, and for local economy. } \\
\text {-Explaining that only this project would be } \\
\text { implemented as PPP, and no changes were } \\
\text { required for entire project implementation } \\
\text { process. } \\
\text {-Making public sector entities part of project } \\
\text { implementation process. } \\
\text { Capacity building: } \\
\text {-Helping government entities to administer PPP } \\
\text { contracts with assistance of international } \\
\text { consultants. }\end{array}$ \\
\hline $\begin{array}{l}\text { Employees and } \\
\text { management at } \\
\text { airport }\end{array}$ & $\begin{array}{l}\text { - Transforming airport from public } \\
\text { entity into private operator meant } \\
\text { government employees had to resign as } \\
\text { government employees and transfer as } \\
\text { private employees. } \\
\text {-Drastic changes in administration } \\
\text { and operation of airport caused fear, } \\
\text { confusion, loss, and resistance among } \\
\text { employees who refused to join new } \\
\text { operator. }\end{array}$ & $\begin{array}{l}\text { - Change of organizational } \\
\text { identity and culture from public } \\
\text { to private. } \\
\text {-Signing of new contract and } \\
\text { abidance by new rules and } \\
\text { regulations working for private } \\
\text { sector company. } \\
\text {-Saudi employees having to work } \\
\text { under project company owned by } \\
\text { foreign businesses and bosses' } \\
\text {-New sets of technical and } \\
\text { administrative skills and higher }\end{array}$ & 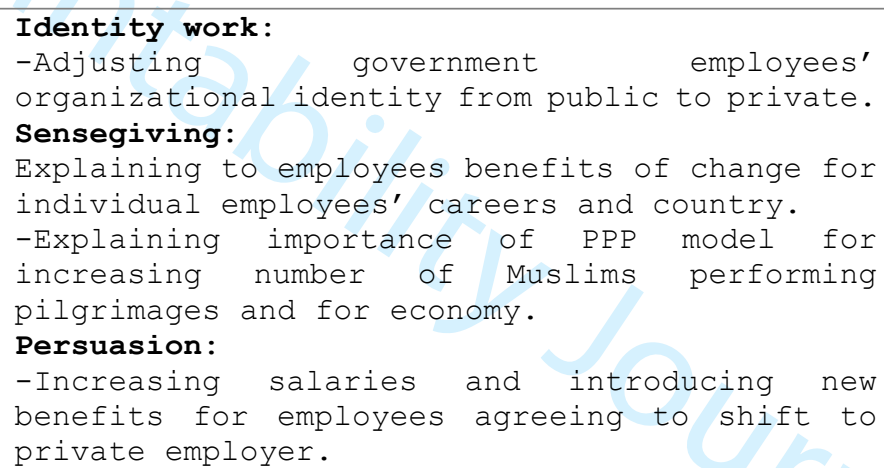 \\
\hline
\end{tabular}




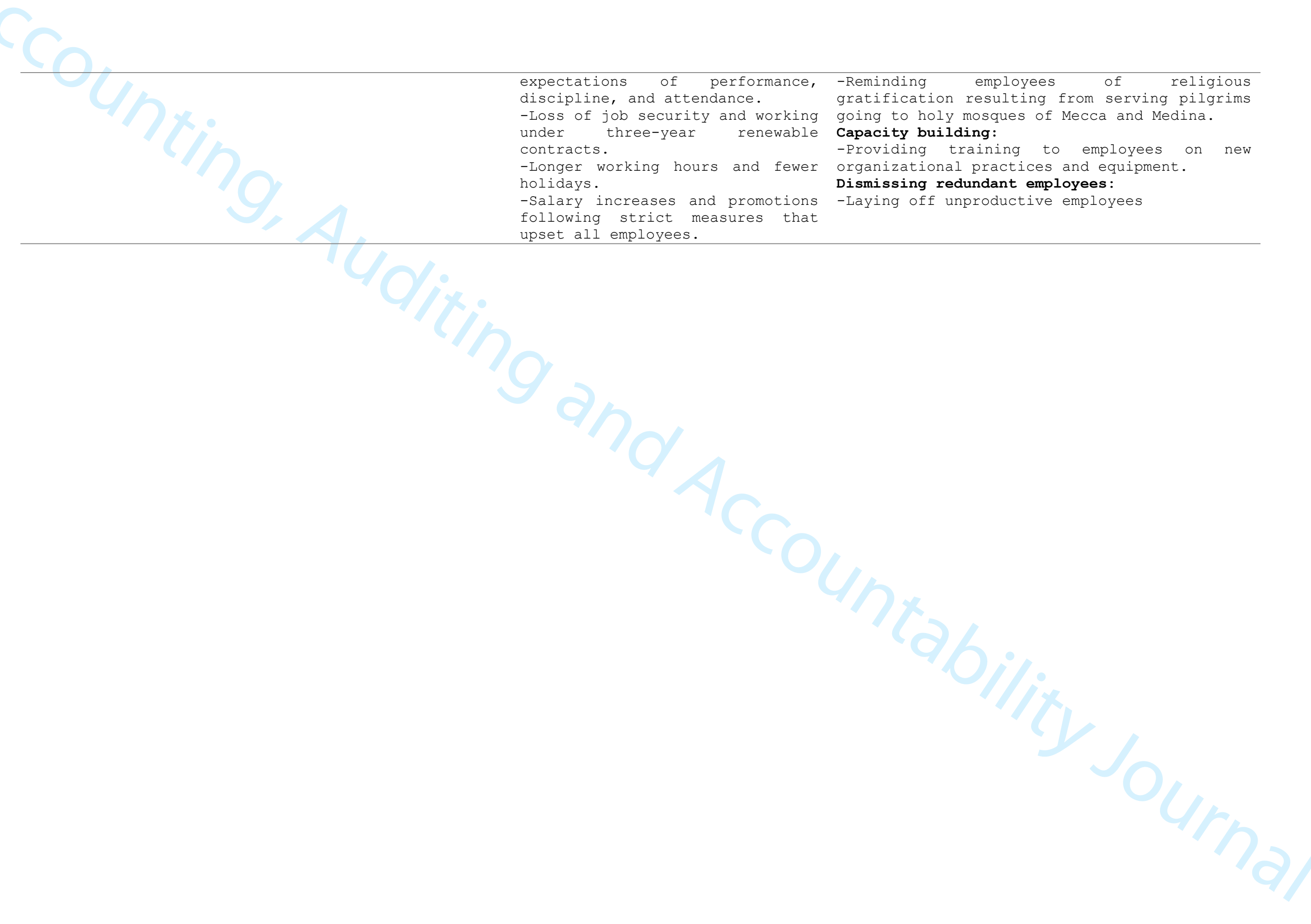


Figure 2: Process model displaying institutional work and power dynamics involved in PPP project implementation

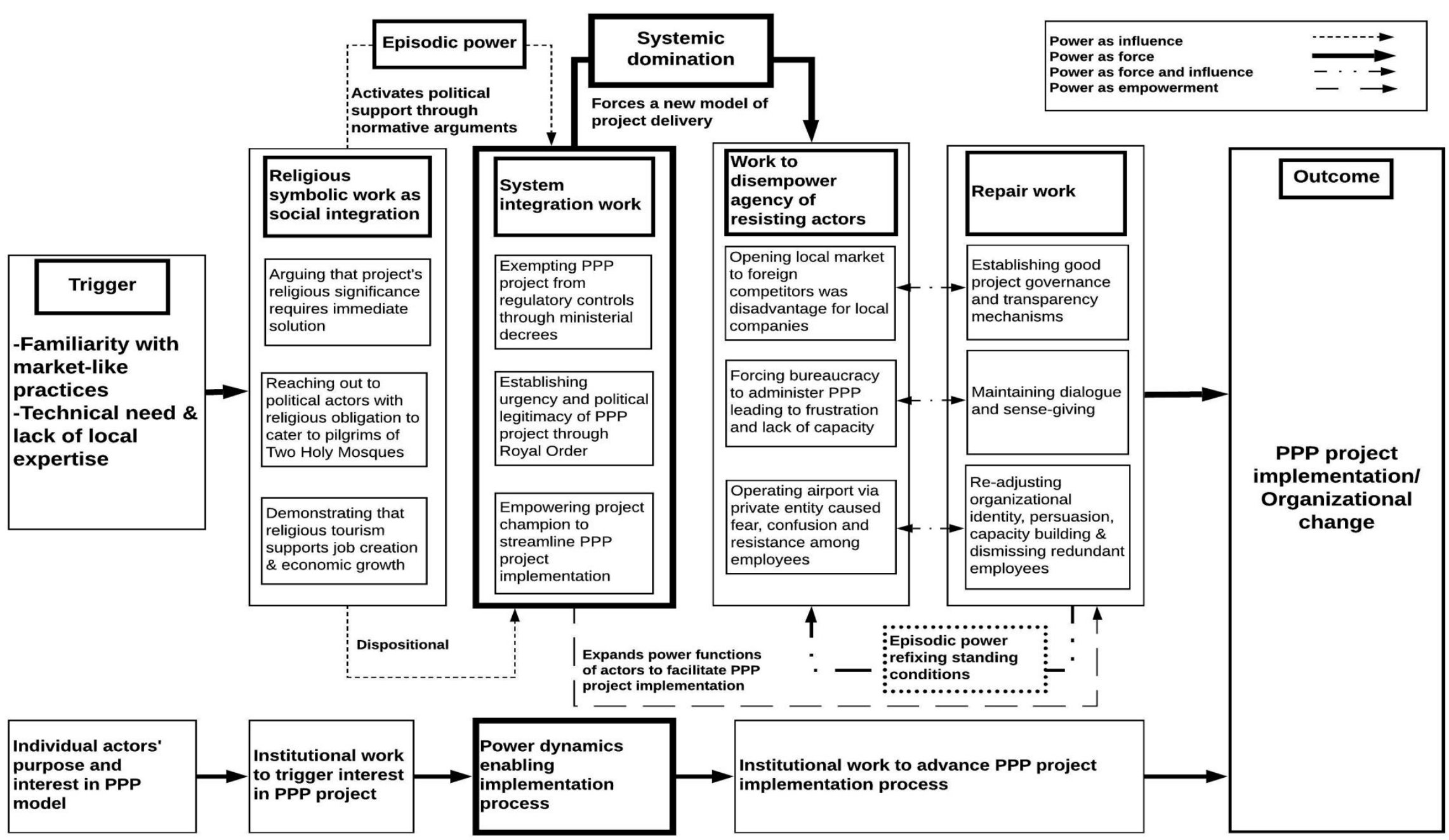

